$$
\begin{aligned}
& \text { جداسازى و شناسايى باكترىهاى محرى رشد از ريشه سيهر گَياه اسيندى }
\end{aligned}
$$

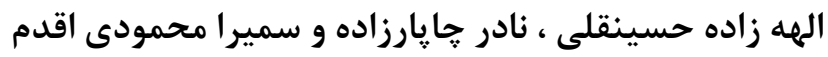

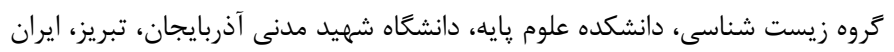

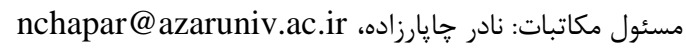

جكيده. برخى از ريزوباكترىها اثرات مفيد بر رشد كياهان دارند. اسِندى (Zygophyllum fabago) يك علف هرز با ارزش دارويى است. در تحقيق

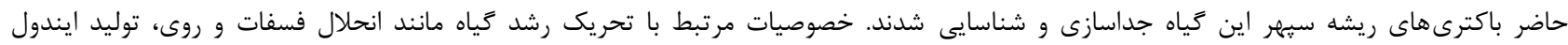

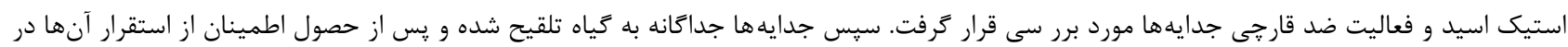

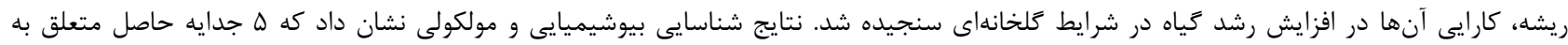

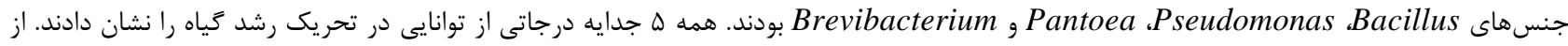

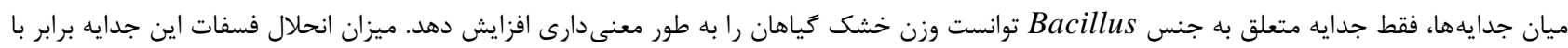

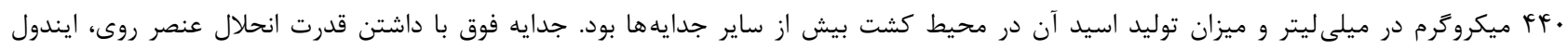

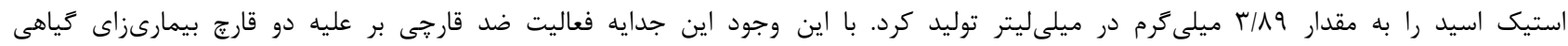
ا ا نشان نداد. Botrytis cinerea, Aspergillus niger

$$
\text { وازههاى كليدى. انحلال فسفات، ايندول استيك اسيد، باكترى، ريشه، ضد قارج }
$$

\title{
Isolation and characterization of plant growth-promoting bacteria from Syrian bean caper (Zygophyllum fabago) rhizosphere
}

\author{
Elaheh Zadeh Hosseingholi, Nader Chaparzadeh \& Samira Mahmudi Aghdam \\ Department of Biology, Faculty of Basic Sciences, Azarbaijan Shahid Madani University, Tabriz, Iran \\ Correspondent author: Nader Chaparzadeh, nchapar@azaruniv.ac.ir
}

\begin{abstract}
Some rhizobacteria have positive effects on plants growth. Syrian bean-caper (Zygophyllum fabago) is a weed plant with medicinal value. This study was conducted to isolate and identify bacteria from Syrian bean-caper rhizosphere. Characteristics associated with plant growth stimulation, such as phosphate and zinc dissolution, production of Indole acetic acid and antifungal activity, were investigated. The isolates were separately inoculated to the plant and after plant root establishment was ensured, their effectiveness in increasing plant growth in greenhouse conditions was measured. Biochemical and molecular identification results showed that five isolates belonged to the genera Bacillus, Pseudomonas, Pantoea, and Brevibacterium. All five isolates showed some degree of plant growth promotion capabilities. Among the isolates, only the genus Bacillus increased the dry weights of plants significantly. The amount of phosphate solubilization for this isolate was $440 \mu \mathrm{g} \mathrm{ml}^{-1}$ and its acid production in the culture medium was higher than that in other isolates. The isolate had zinc solubilisation capability and produced $3.89 \mathrm{mg} \mathrm{ml}^{-1}$ indole acetic acid. However, this isolate did not show antifungal activity against two fungal pathogens of Aspergillus niger and Botrytis cinerea.
\end{abstract}

Keywords. antifungal activity, bacteria, indole-acetic acid, phosphate solubilization, root 
بوده و به صورت پِماد براى بهبود بيمارىهاى يوستى و زخمهاى

خارجى استفاده مىشود (Khan et al., 2014).

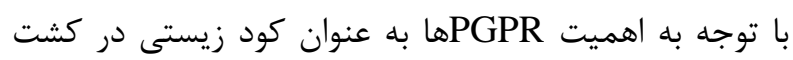

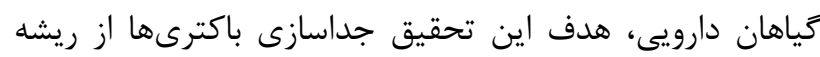

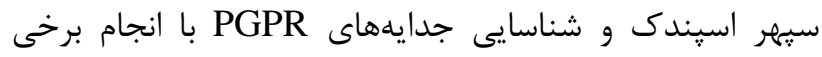
بررسىهاى مولكولى و فيزيولوزيكى نظير توانايى توليد اكسين و

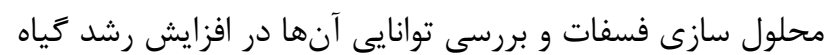
مذكور در شرايط آزمايشخاهى بود.

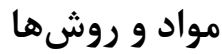
محل و روش ترد آورى نمونه خاك ريشهسيهر

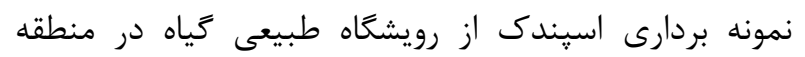

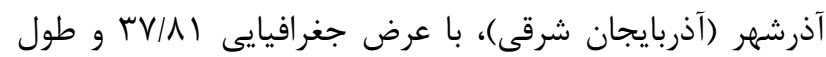

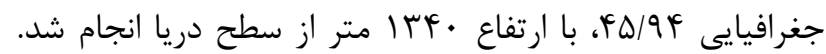
نمونههاى كياهى به همراه ريشه در كيسه استريل به آزمايشكاه منتقل شد.

جداسازى باكترىها ريشه كياه با رعايت شرايط استريل به قطعات كوجى بريده شدها و سيس به ارلنهاى حاوى سرم فيزيولوزى استريل منتقل شد. نمونهها حدود نيم ساعت روى همزن با دور • •1 بر دقيقه قرار

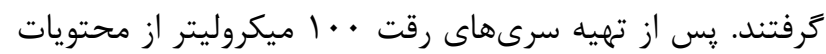

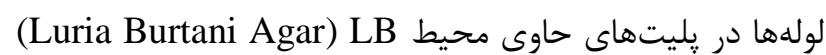

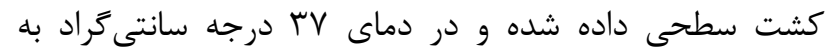

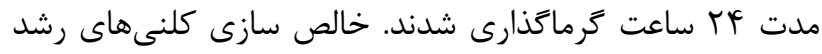

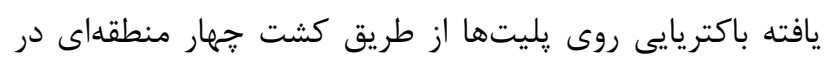

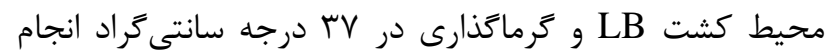
شد. جدايههاى خالص شده دركليسرول •r درصد و در در فريزر

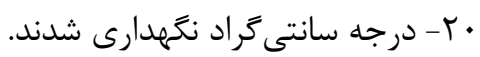

شناسايى ويزَّىهاى ريخت شناسى و بيوشيميايى جدايهها

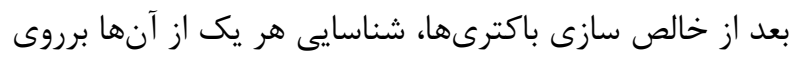

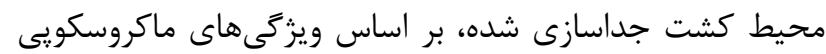

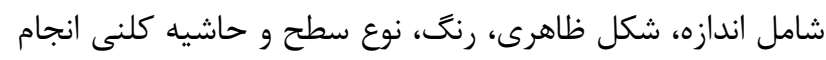

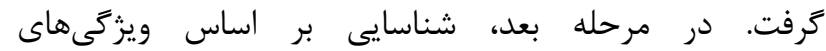
ميكروسكويى شامل شكل باكترى (ميلهاى، كروى، ماريبيجى)،

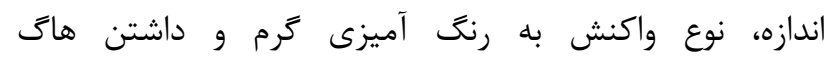
(Bartholomew \& Mittwer, 1950) از طريق استفاده از محيط كشت نيمه جامد Sulfide ) SIM (Twedt et al., 1969) (Indole Motility Medium كاتالاز از طريق اضافه كردن قطرات باكتريايى (Taylor \& Achanzar, 1972) و آزمون اكسيداز از لاز
مقلهمه

براى تامين عناصر ضرورى گَياه عموما از كودهاى شيميايى استفاده مىشود. با اين وجود، به غير از مسايل اقتصادى، انتقال

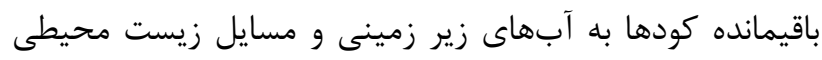

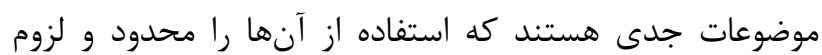

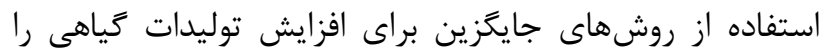

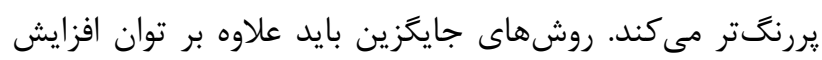

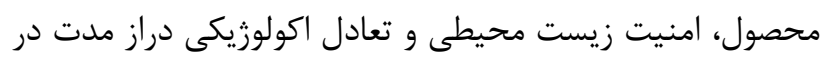

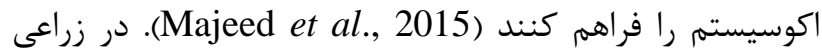

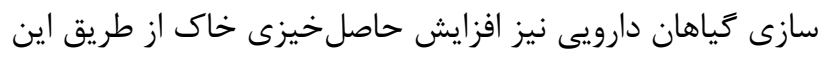

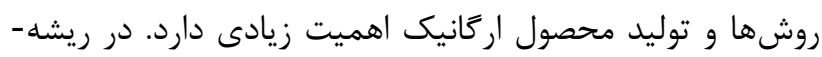

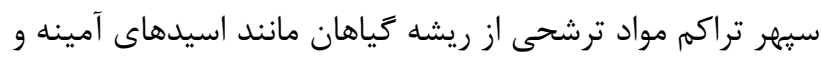

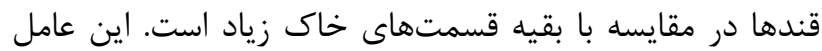

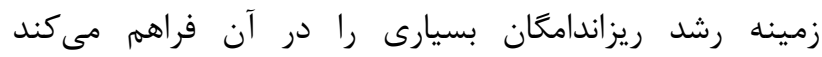

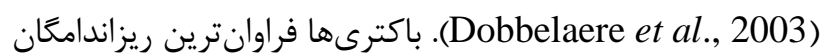

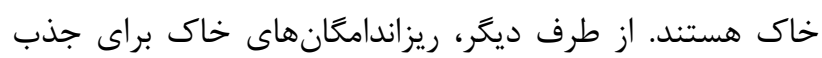

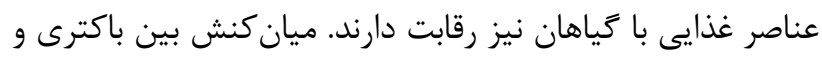

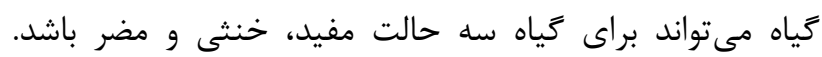

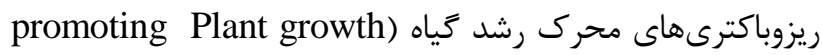
bacteria or PGPR

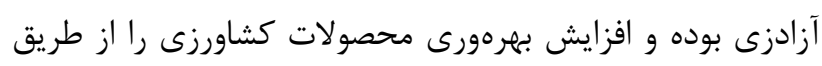

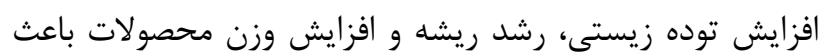

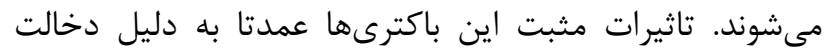

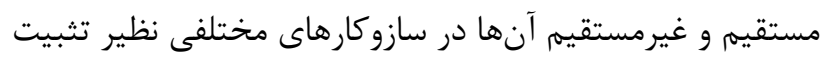

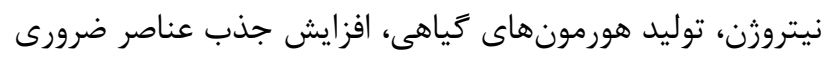

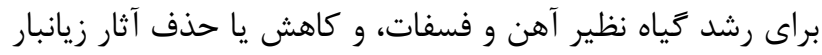

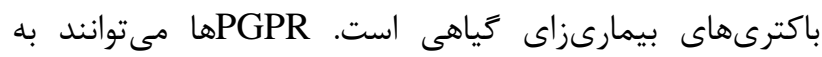
صورت خارج سلولى در ريشهسيهر و روى سطح ريشه و بله

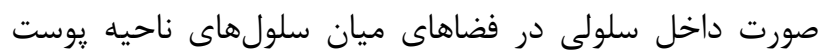
ريشه مستقر شوند. تنها درصد كمى از باكترىها رشد كياه را در

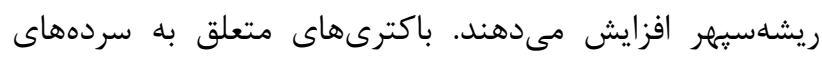
و Pseudomonas ، Bacillus Azetobacter هاى خارج سلولى هستند Agrobacterium از مهمترين APR (Antoun, 2013; Bhattacharyya \& Jha, 2012) اسيندك (Zygophyllum fabago L.) كياهى علفى و دوليه متعلق به تيره قيجيان است. در بيشتر مناطق دنيا اسيندى

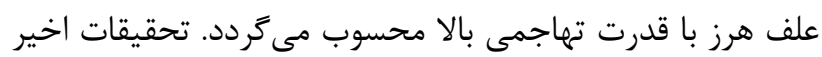

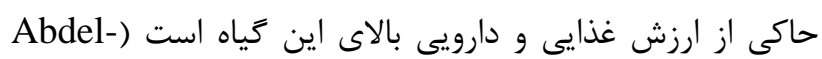
Hamid et al., 2013

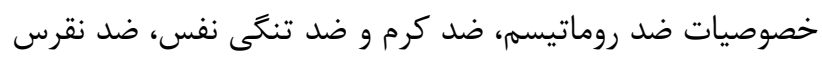




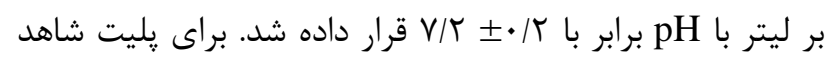

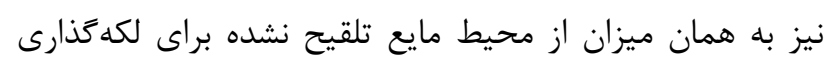

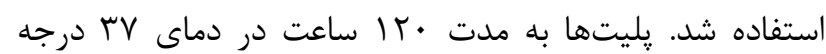

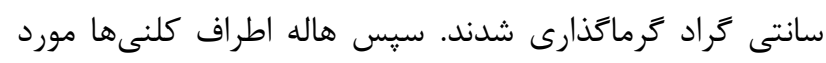

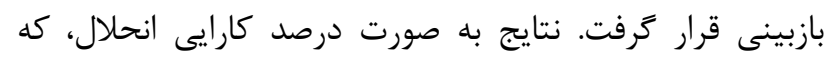
حاصل تقسيم قطر حلاليت بر قطر رشد است، كزارش شد شد (Dawwam et al., 2013; Felsenstein, 1985 ) سنجش كمى انحلال نيز جدايهها در محيطهاى جداكانه

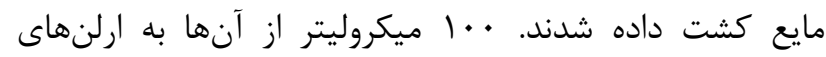

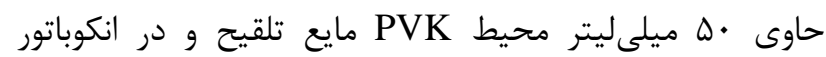

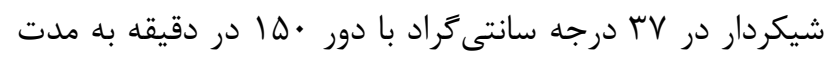

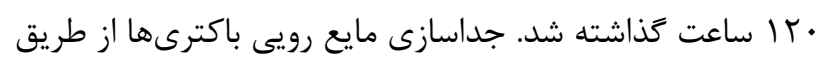

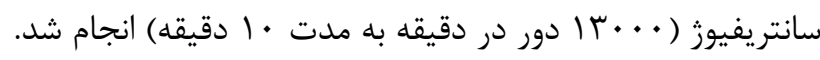

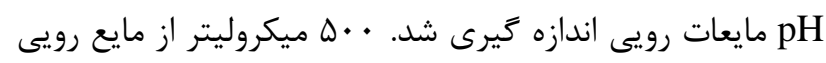

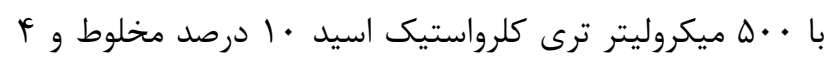

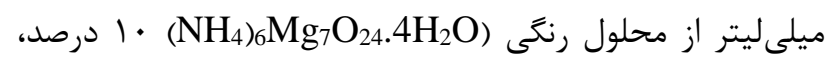

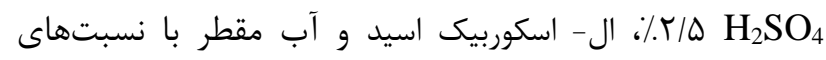

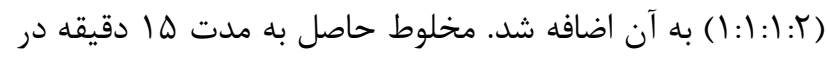

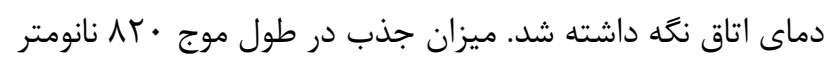
تعيين و با استفاده از منحنى استاندارد

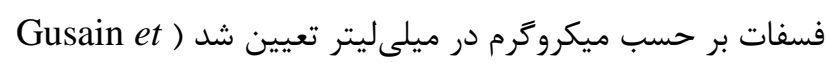
.(al., 2015

\section{سنجش انحلال كيفى عنصر روى توسط جدايهها}

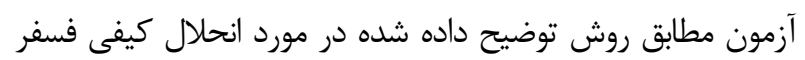

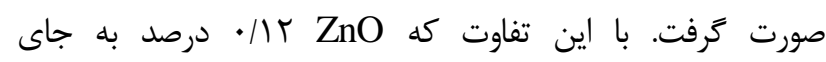

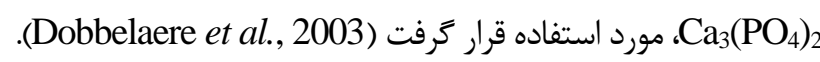
سنجش توليد اكسين يا ايندول استيك اسيد (IAA) توسط جدايهها

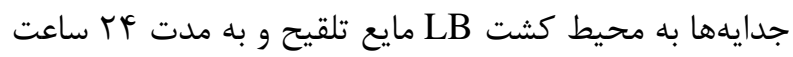

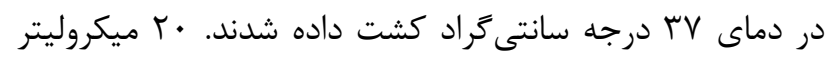

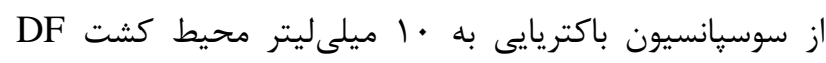

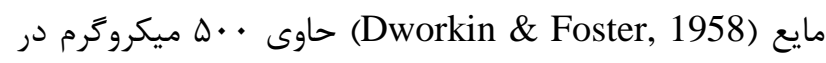

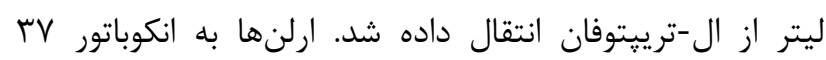

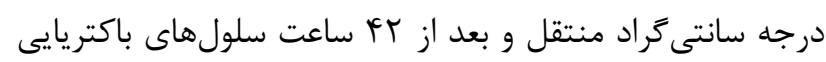

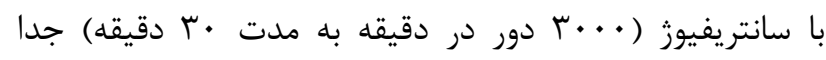

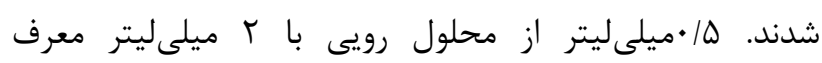
Salkowski آب مقطر، ه ميلىليتر

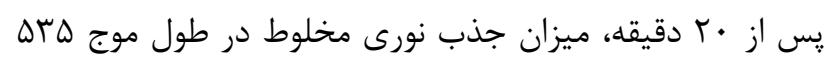

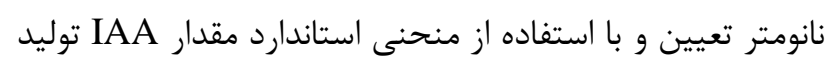

طريق انتقال كلنىهاى باكتريايى به كاغذ صافى حاوى معرف

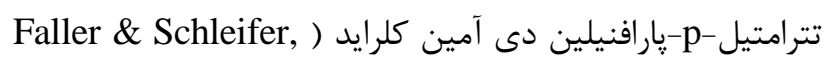

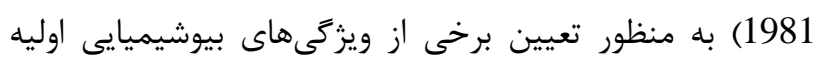

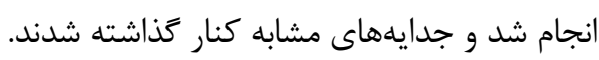

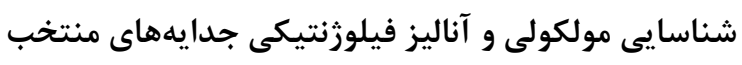
شناسايى تكميلى جدايههاى منتخب با تكثير و تعيين توالى 16S rDNA

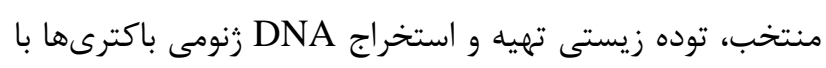
روش جوشاندن (Queipo-Ortuo et al., 2008) انجام شد.

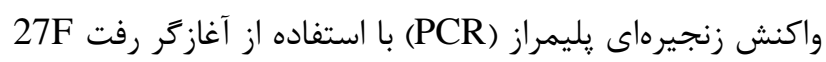

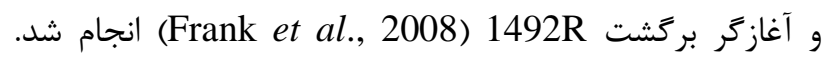

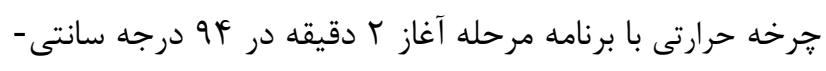

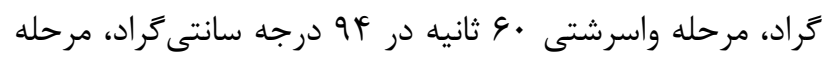

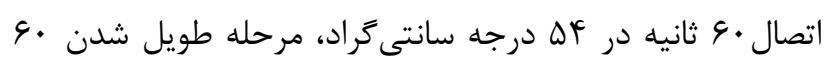

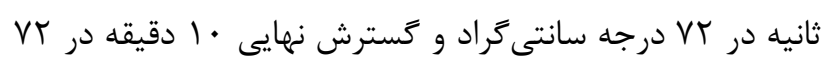

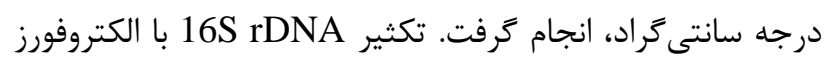

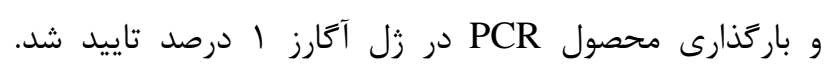

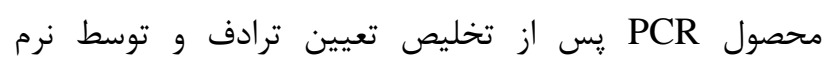

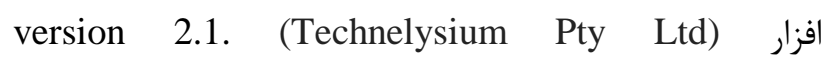
ChromasPro

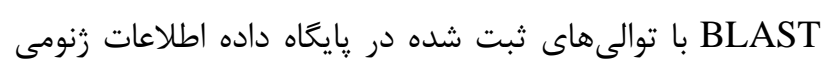
Yoon et al., ) Eztaxon (http://www.ezbiocloud.net) 2017) مقايسه و ميزان شباهت آن با باكترىهاى مختلف ثبت

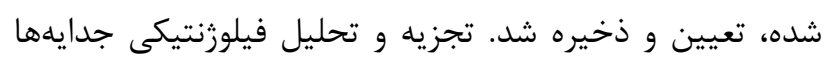

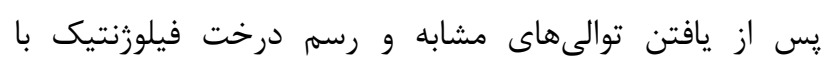

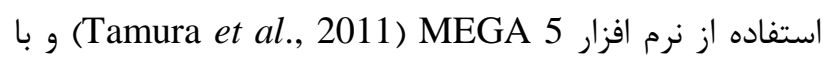

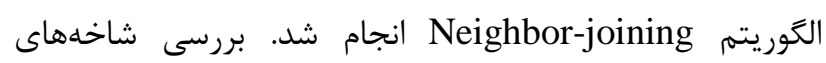

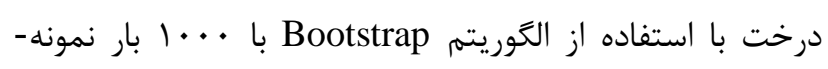
كيرى انجام شد (Felsenstein, 1985).

سنجش كيفى و كمى انحلال فسفات معدنى توسط جدايهها

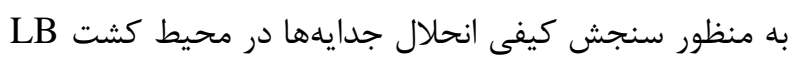
مايع كشت داده شدند. سلول هاى باكتريايى با سانتريفيوز (...

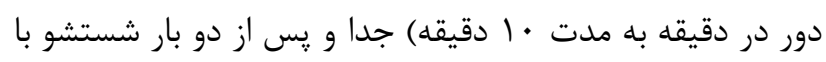

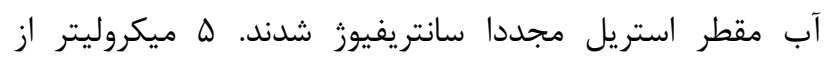

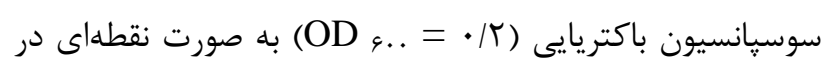

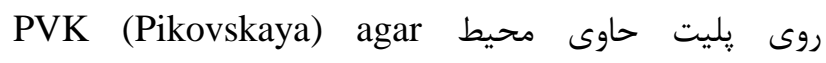
$\left(\mathrm{NH}_{4}\right)_{2} \mathrm{SO}_{4}$ متشكل از كلوكز • (Pikovskaya, 1948) ه/ • گرم، كرم،

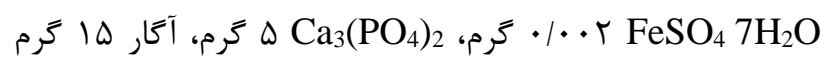


فيزيولوزى / | درصد منتقل شد. بعد از هم زده شدن (•|| دور در دقيقه) و تهيه سريال رقت، .ال ميكروليتر از محتويات لولهها

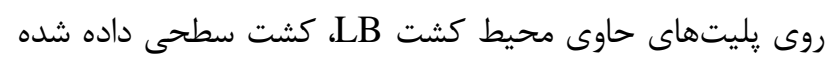

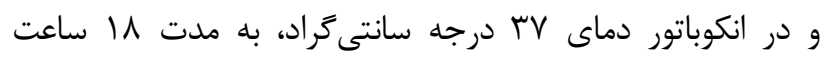
كرماكذارى شدند (Simons et al., 1996).

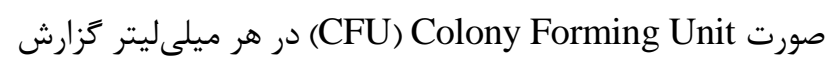

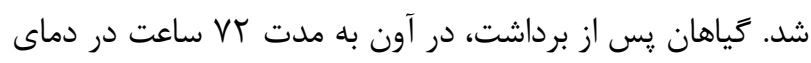

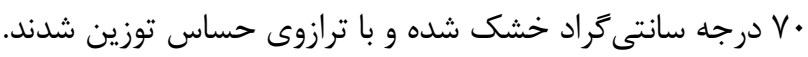

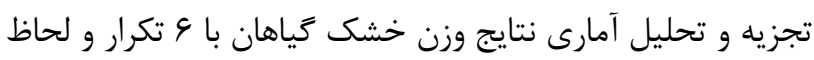

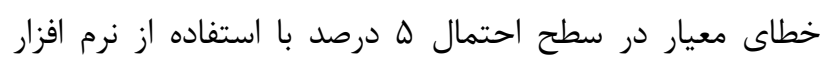
S نسخه IVSS

\section{نتايج}

\section{جداسازى و ويزَّى هاى بيوشيميايى و ريختشناسى جدايهها}

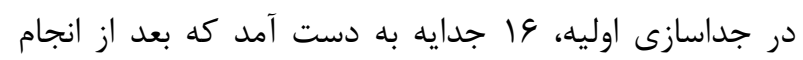
تستهاى اوليه بيوشيميايى و ريخت شناسى و حذف جدايههاى إليه

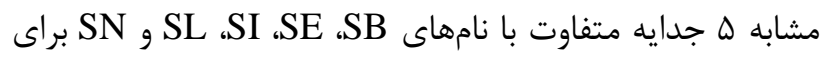
ادامه بررسى ها انتخاب شدند. خلاصهاى از ويزّكى هاى اين سويهها در جدول المدا آمده است.

\section{شناسايى مولكولى سويههاى منتخب و رسم درخت فيلوزنتيك المده}

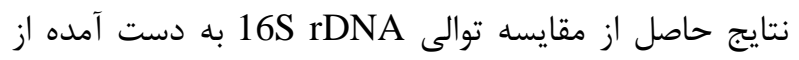

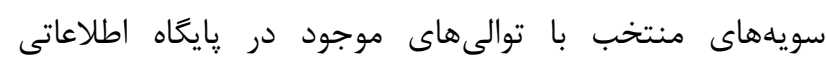
EzTaxon

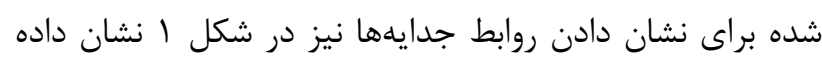
شده است.

بررسى در شيشه (In vitro) خصوصيات مرتبط با تحريك رشد

در جدايهها

بررسى توانايى محلولسازى فسفات نشان داد كه همه هـ جدايه

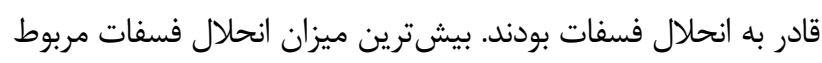

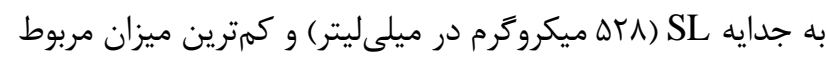

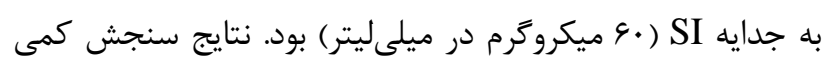

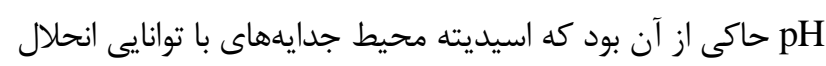

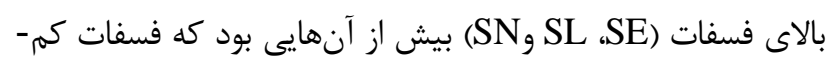
ترى (SI , SB) را محلول ساخته بودند.

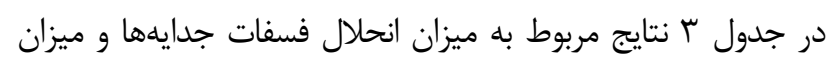

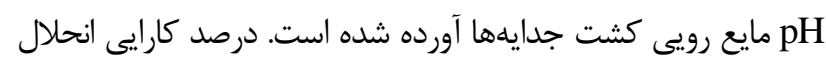

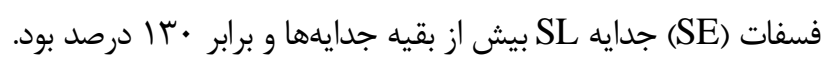

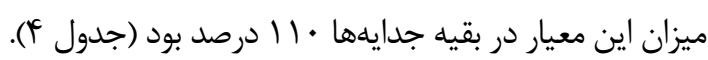

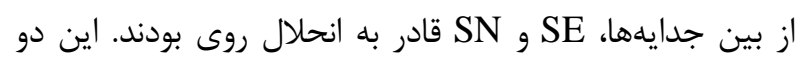

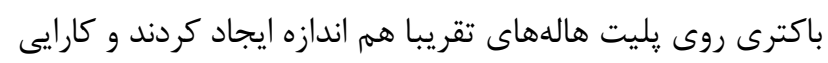

شده برحسب ميكروگرم در ميلىليتر مشخص شد ( Gordon \& (Weber, 1951 سنجش فعاليت ضد قارجى توسط جدايهها

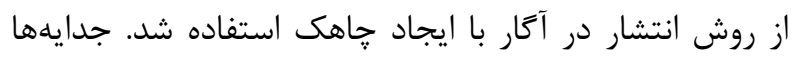

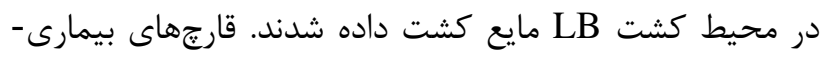

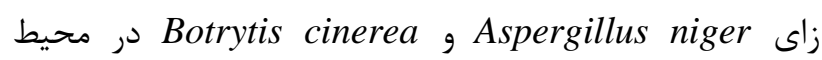
Sabaroud Dextrose Agar (SDA) قارجها خراشيده شده و در • إ ميلىليتر سرم فيزيولوزى نرمال

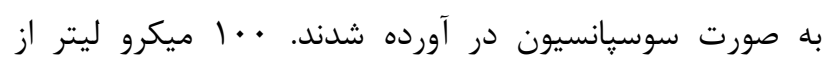

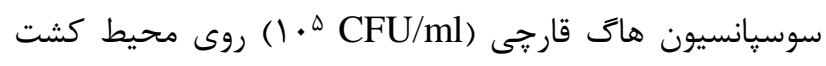
SDA

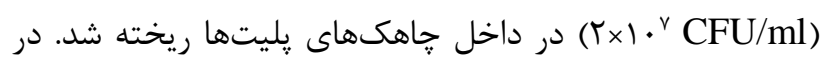

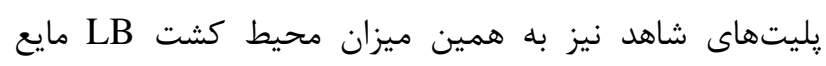

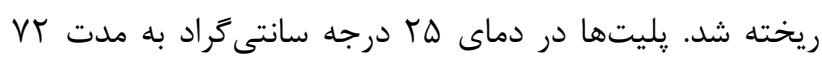

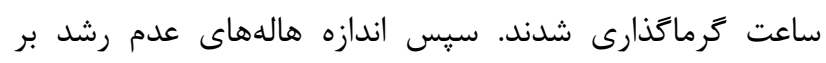

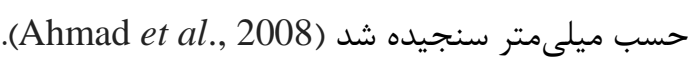

\section{آماده سازى بذرها و تهييه مايع تلقيح}

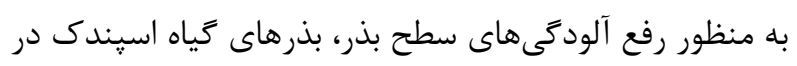

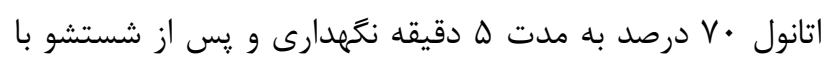

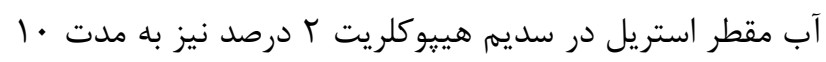

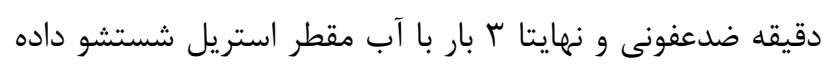

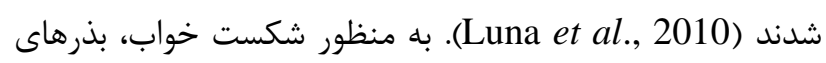

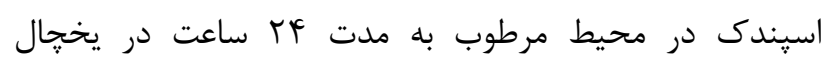

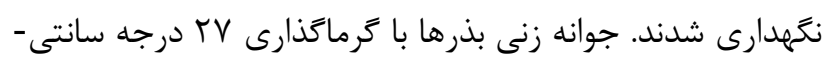

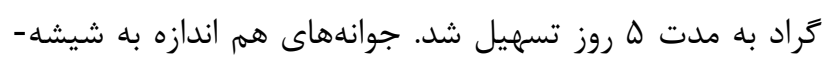

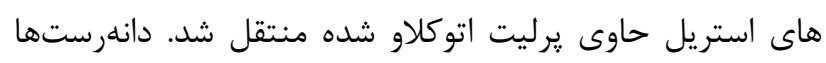

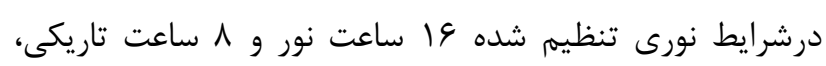

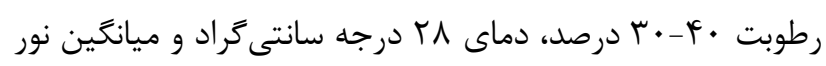

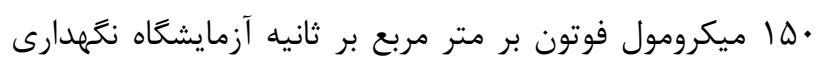

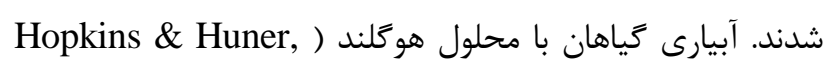

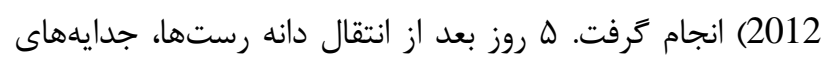

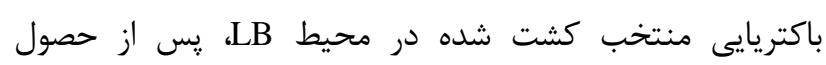

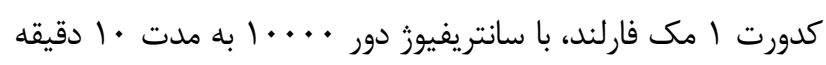

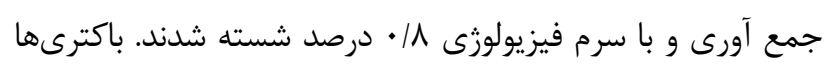

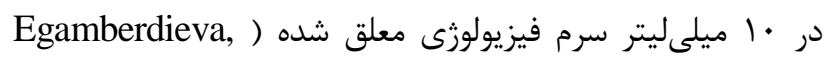

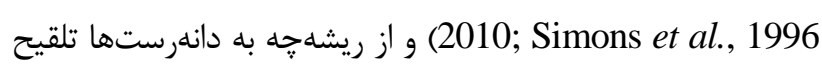
كرديد. به گروه شاهد سرم فيزيولوزى تلقيح شد.

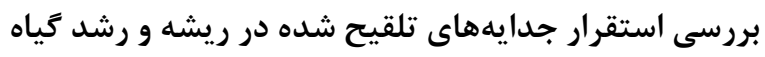

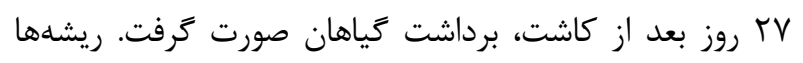

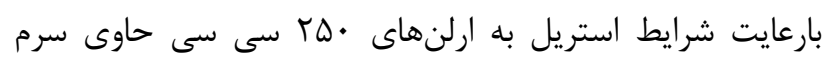




$$
\text { جدول ا- برخى از ويزگى هاى بيوشيميايى و ريخت شناسى جدايهاى منتخب. }
$$

Table 1. Some biochemical and morphological characteristics of selected isolates.

\begin{tabular}{|c|c|c|c|c|c|c|c|}
\hline ميكروسكويى شكل & حركت & تست كاتالاز & تست اكسيداز & توليد هاك & نوع كرم & ويزَى كلنى & نام انتخابى براى جدايه \\
\hline ميلداى كوتاه & + & + & - & - & - & 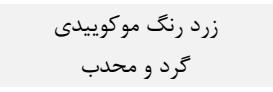 & SB \\
\hline ميلهاى & + & + & + & + & + & سفيد رنكَ مواج با حاشيههاى & $\mathrm{SE}$ \\
\hline ميلهاى كوتاه & + & + & - & - & - & كيمه شفاف زمد محد & SI \\
\hline ميلهاى & + & + & + & - & - & سفيد مايل به زرد & SL \\
\hline ميلهاى كوتاه & - & + & + & - & + & سفيد مايل به خاكسترى & $\mathrm{SN}$ \\
\hline
\end{tabular}

جدول r- ميزان شباهت جدايههاى منتخب با نزديكترين گونه ثبت شده در پايكاه EzTaxon.

Table 2. The similarity of selected isolates with the closest species registered at the EzTaxon database.

\begin{tabular}{|c|c|c|c|}
\hline 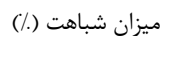 & Accession number & نزديكترين باكترى شناخته شده در EzTaxon & نام انتخابى \\
\hline 99.6 & EF688012 & Pantoea vagans & SB \\
\hline 100 & ASJD01000027 & Bacillus safensis & SE \\
\hline 100 & AG233423 & Pantoea agglomerans & SI \\
\hline 100 & AM293567 & Pseudomonas mohnii & SL \\
\hline 100 & AM747813 & Brevibacterium frigoritolerans & SN \\
\hline
\end{tabular}

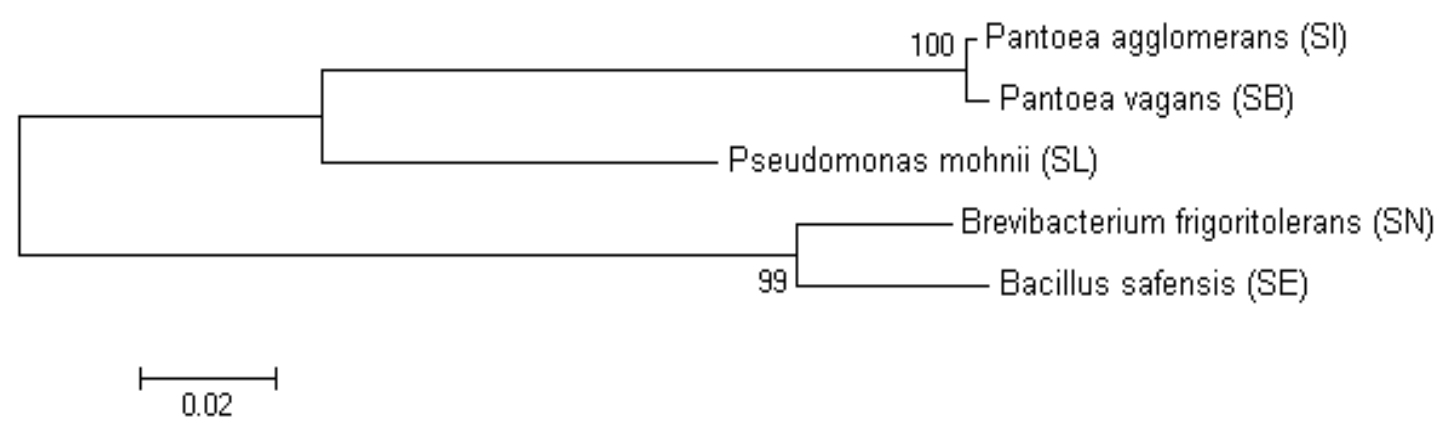

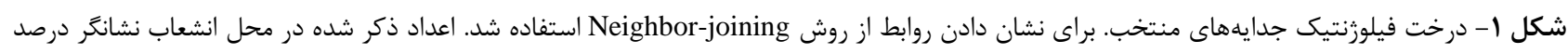

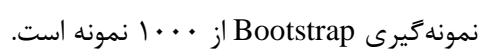

Fig.1. Phylogenetic tree of selected isolates. The Neighbor-joining method was applied to illustrate relationships. The numbers at the branch points represent a sample bootstrap percentage of 1000 samples.

ميلى

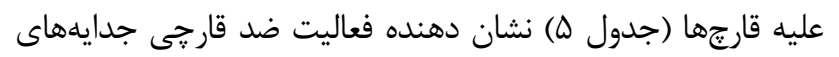
عليه هر دو قارج بيمارىزاى مورد استفاده بود. جدايه SI وSB عليه قارج SN

$$
\text { فعاليت ضد قارجى نشان نداند. }
$$

انحلال روى مربوط به آنها • 11 درصد بود (جدول \&). بررسى نتايج حاصل از توانايى توليد ايندول استيك اسيد مشخص كرد كه بيشترين ميزان توليد ايندول استيك اسيد مربوط به جدايه SB با لوائ ميلى گ/91 SN و SL ، SI ، SE 


$$
\text { جدول r - غلظت فسفات محلول و نه نهايى مايع رويى كشت جدايهها در محيط PVK مايع به مدت • r ا ساعت. }
$$

Table 3. Phosphorus concentration and final pH of the supernatants cultured isolates in the PVK Broth medium after incubation for 120 hours.

\begin{tabular}{|c|c|c|}
\hline $\mathrm{pH}$ & غلظت فسفات حل شده (ميكروكرم در ميلىليتر) & 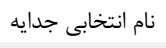 \\
\hline gIAT & 9 & SB \\
\hline$\Delta / r$. & fr. & SE \\
\hline 9190 & 4. & SI \\
\hline$\Delta / T \Delta$ & $\Delta r \Lambda$ & SL \\
\hline$\Delta / \Delta \Lambda$ & rq. & SN \\
\hline
\end{tabular}

$$
\text { جدول F - درصد كارايى انحلال فسفر و روى جدايههاى باكتريايى. }
$$

\begin{tabular}{|c|c|c|}
\hline كارايى انحلال روى & كارايى انحلال فسفات & نام انتخابى جدايه \\
\hline- & 11 & SB \\
\hline 11. & 11. & SE \\
\hline- & 11. & SI \\
\hline- & ir. & SL \\
\hline 11. & 11. & SN \\
\hline
\end{tabular}

Table 4. Phosphorus and Zinc solubilization efficiency percentage of bacterial isolates.

جدوله - اندازه هاله بازدارندگى رشد قارجهاى Botrytis cinerea, Aspergillus niger بر حسب ميلىمتر.

Table 5. The size of the inhibition zone of mycelial growth of Aspergillus niger and Botrytis cinerea in millimeters

\begin{tabular}{cccccc} 
SN & SL & SI & SE & SB & \\
\hline- & 10 & 11 & - & 10 & Aspergillus niger \\
ir & 10 & 1. & - & 14 & Botrytis cinerea
\end{tabular}

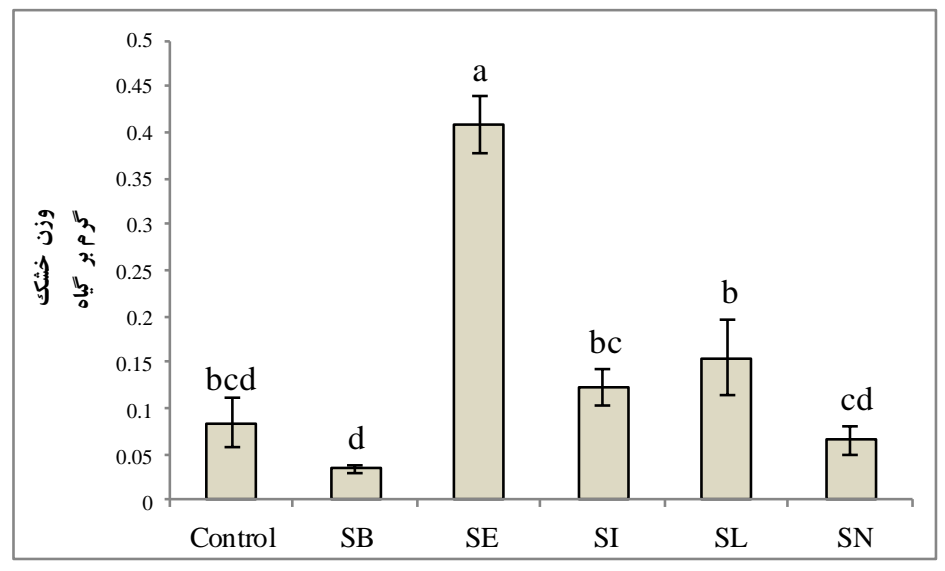

شكل r - وزن خشك كياهان تيمار شده با جدايههاى باكتريايى. مقادير ميانكين شش تكرار SE هستند. حروف متفاوت بيانكر اختلاف معنى دار در سطح P > 0.05 است

Fig. 2. Dry weights of plants treated with bacterial isolates. The values are the average of six replicates \pm SE. Means followed by different letters show a significant difference at the level of $\mathrm{P}<0.05$. 
اسيدهاى غير آلى مانند هيدروكلريك اسيد همجنين مىتواند آند

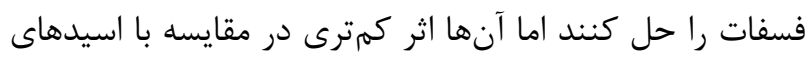

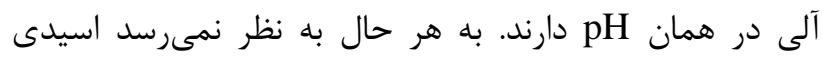

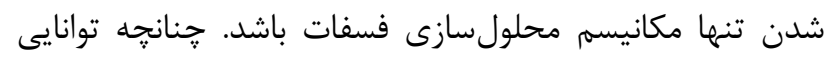

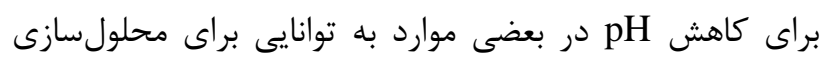

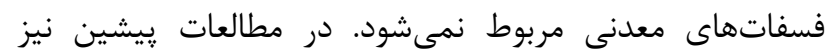

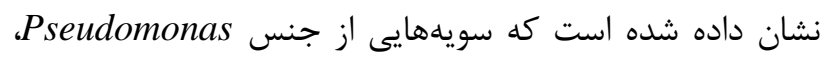
Rhizobium و Bacillus

هستند (Khan et al., 2009).

در مطالعات كذشته B. frigoritolerans قادر به حل فسفات

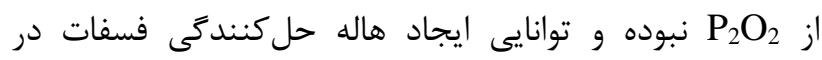

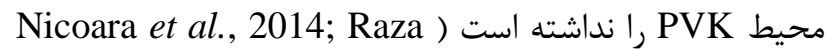

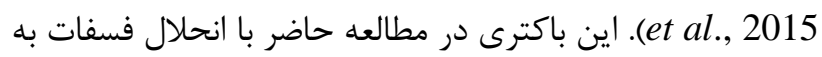

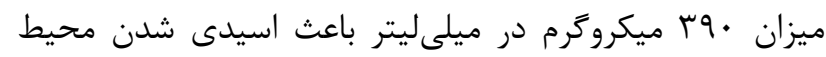
كشت نيز گرديد. ميزان انحلال فسفات باكترى P. agglomerans

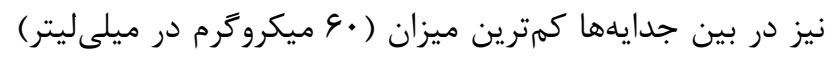

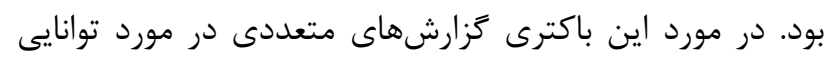

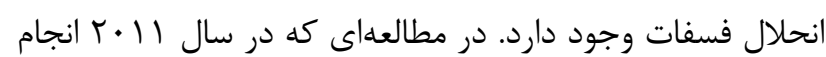

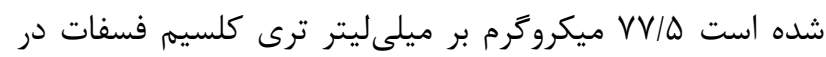

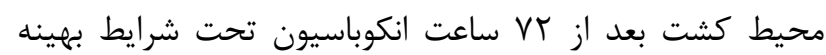

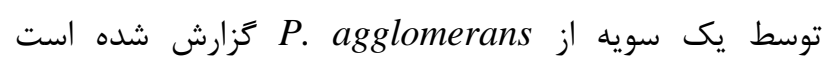
(Mishra et al., 2011) P. agglomerans R-42 ميكروخرم بر ميلىليتر براى سويه

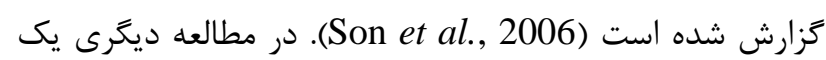

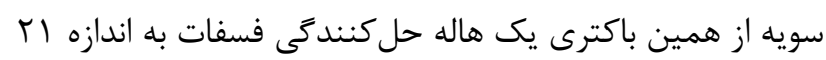
ميلىمتر ايجاد كرده است (Malboobi et al., 2009).

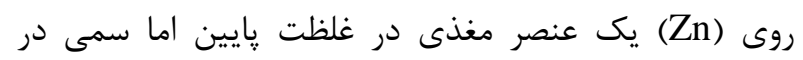

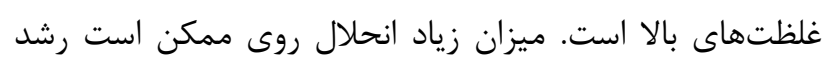

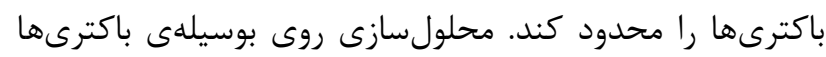

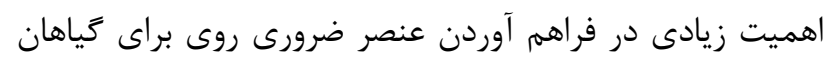

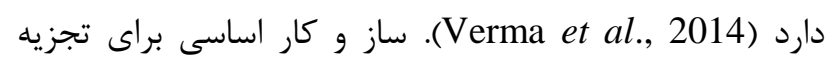
تركيبات حاوى روى، ترشح اسيدهاى آلى است كه با كاهش

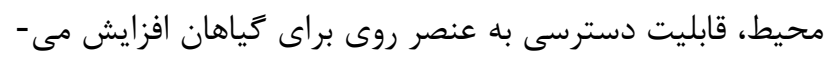

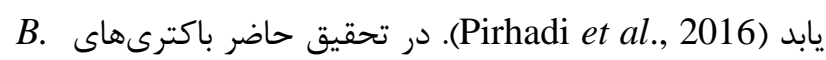
ا Safensis

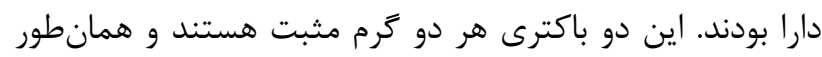

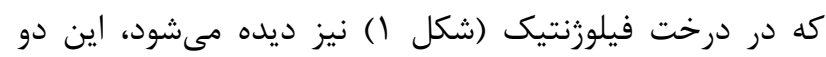

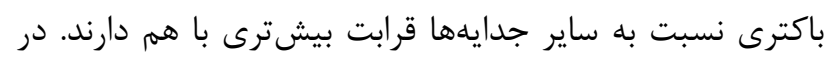

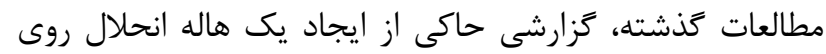

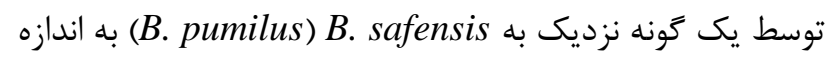

ميزان استقرار جدايهها در ريشه و تاثير آنها در رشد كياه اسيندى در شرايط كلخ إنانهاى

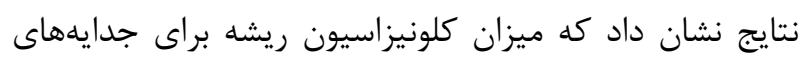

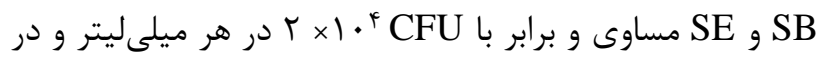

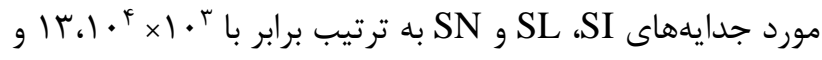

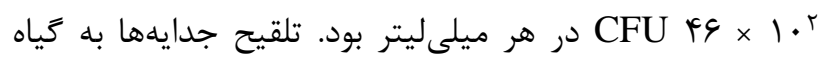

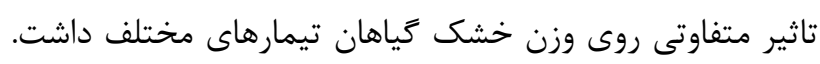

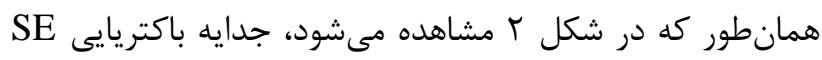

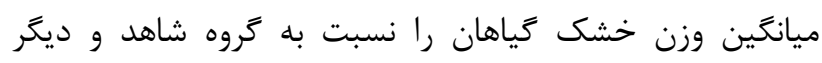
جدايهها به طور معنى دارى افزايش داد.

\section{بحث}

نتايج حاصل از شناسايى مولكولى (جدول Y)، شباهت

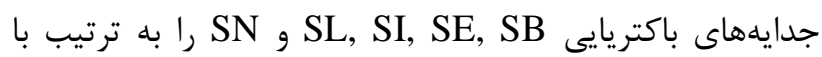

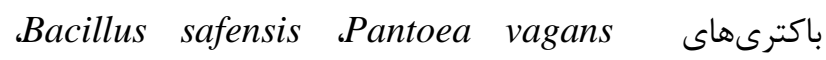
9 Pseudomonas mohnii ‘Pantoea agglomerans Brevibacterium frigoritolerans ريختشناسى و بيوشيميايى تعيين شده (جدول () نيز نتايج

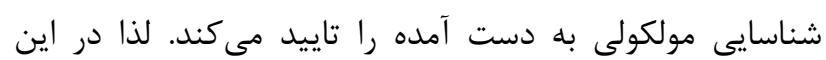

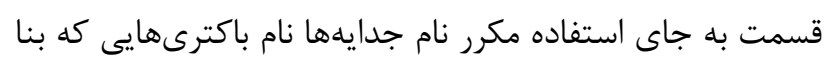
به تستهاى اوليه و مولكولى بيشترين تشابه را به جدايه جدايهها

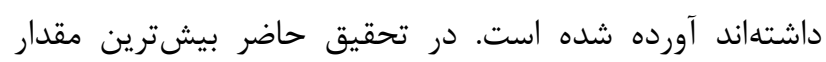

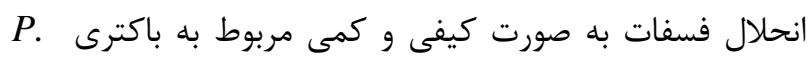

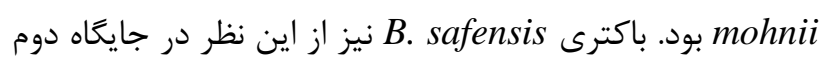

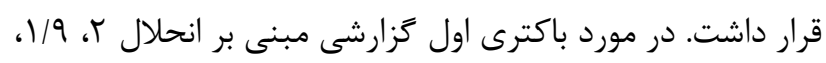

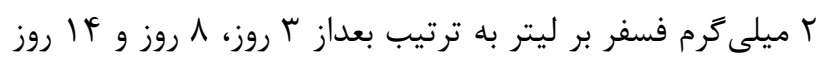

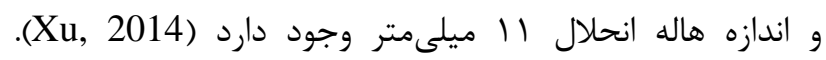

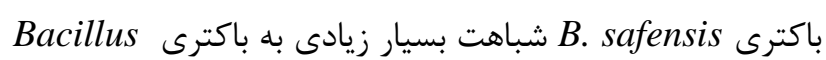
pumilus

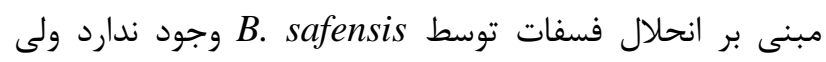

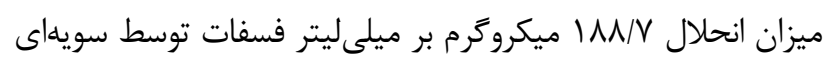

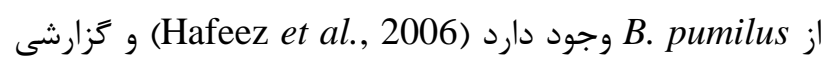

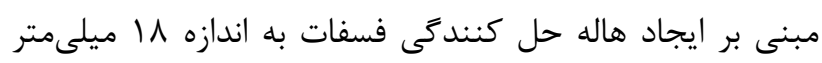

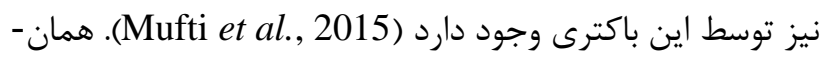

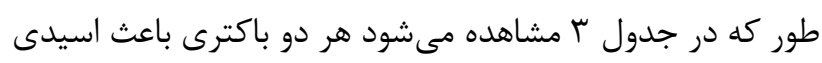

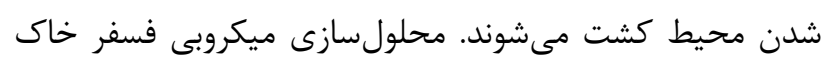

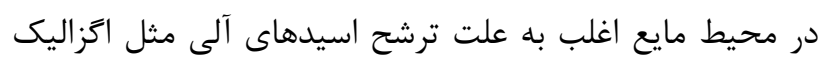

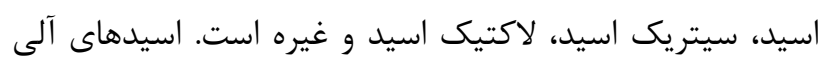

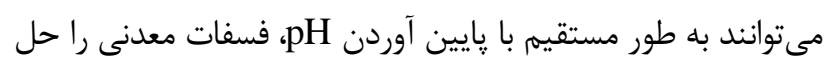

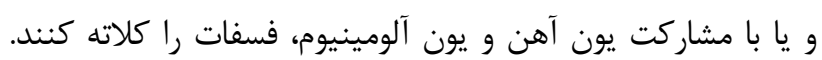


P. PTA-AF1 به علت تلقيح agglomerans در مطالعه حاضر جدايههاى منسوب به اين دو نوع داكت باكترى هاله

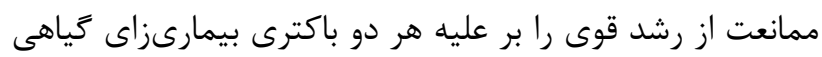

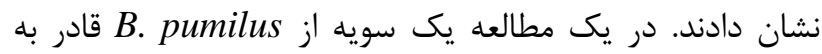

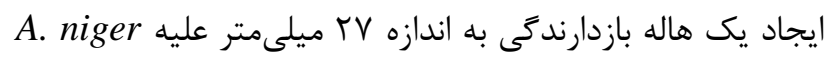
بوده و در يك مطالعه ديكر سويهاى از همين باكترى بN/DV درصد فعاليت ضد قارجى عليه B. cinerea نشان داده است Cherif-Silini et al., 2016; Munimbazi \& Bullerman, )

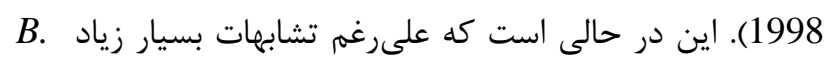

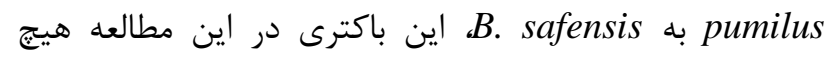

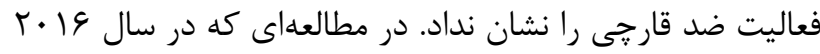

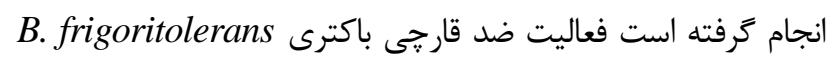
عليه دو قارج مورد استفاده در اين مطالعه منفى بوده است Cherif-Silini et al., 2016) ضد قارجى ززارش نشده است. در مطالعه حاضر بيشترين فعاليت برايت

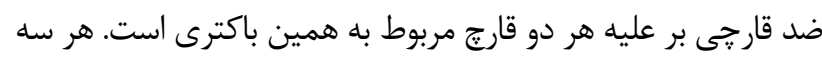

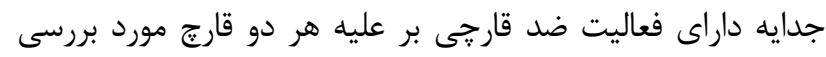

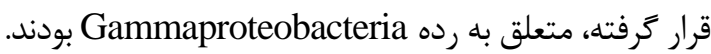

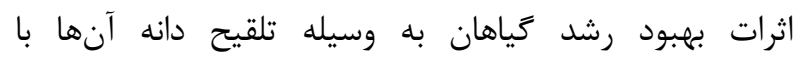

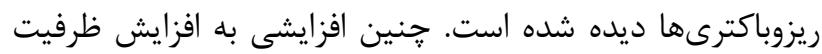

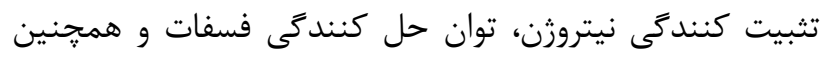
توانيى باكترىها براى توليد سوبستراهاى محرى نيت رشد

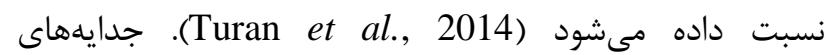

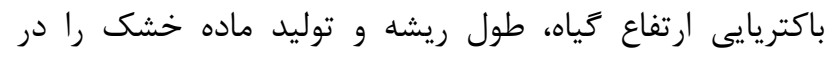

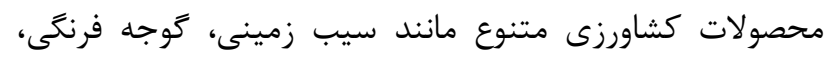

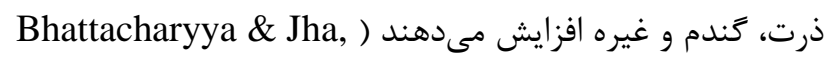

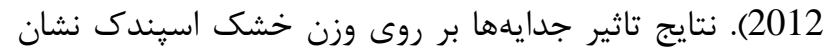
داد كه فقط باكترى B. safensis تاثير معنى دارى در افزايش

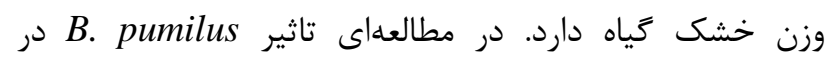
افزايش وزن خشك ريشه و ساقه كياه كَندم مشاهده شده است

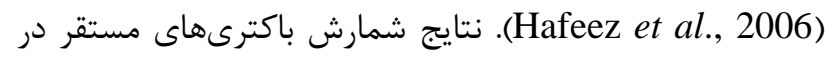

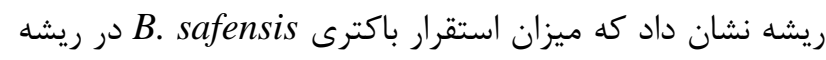

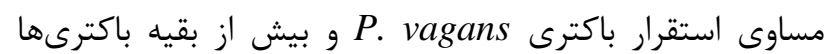

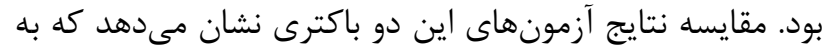

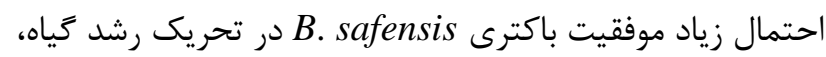
به دليل انحلال فسفات حدود ه برابر بيشتر، قابليت انحلال روى و و و

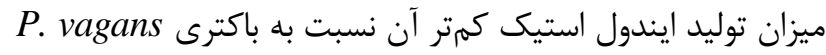

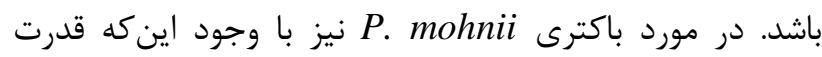

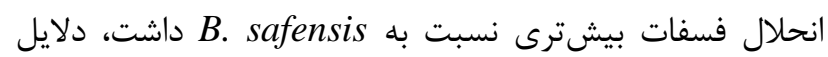

ها ميلىمتر وجود دارد (Sharma et al., 2012). كزارشهاى ديخرى در مورد توانايى انحلال روى توسط باكترى دهاى جنس Mumtaz et al., 2017; Sharma et ) وجود دارد Bacillus .(al., 2012 اكسين يا IAA به وسيله اكثر گونههاى باكتريايى توليد مىشود.

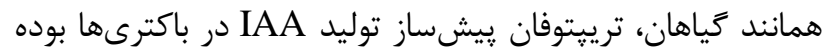

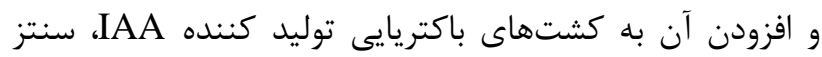

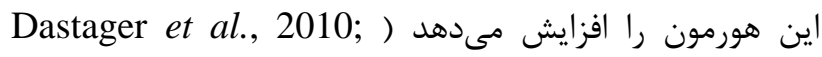
به عنوان مولكول سيخنال مهرم IAA .Sharma et al., 2012 در تنظيم نمو كياه عمل مى كند. ميزان توليد IAA به وسيله

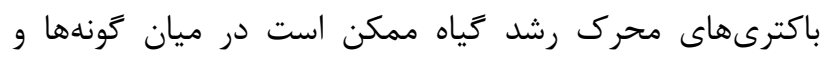
سويهها بسته به شرايط كشت و قابليت دسترسى به سوبسترا تحت تاثير قرار گيرد (Ashrafuzzaman et al., 2009). توليد

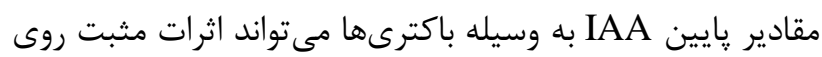
رشد كياه اعمال كند؛ در حالى كه توليد مقادير بالا، يك مشخصه

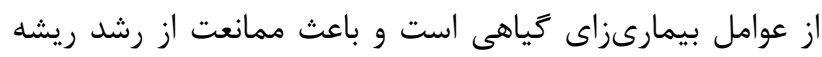

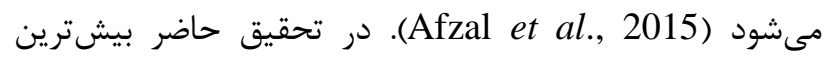

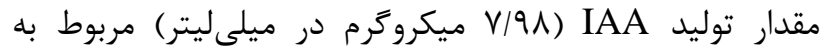

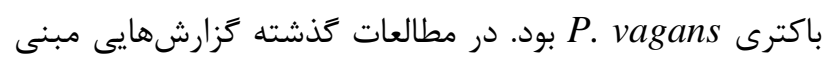

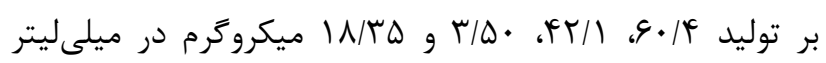
B. C. agglomerans به ترتيب توسط سويههايى از IAA P. mohnii و B. frigoritolerans ،pumilus .(Hafeez et al., 2006; Mishra et al., 2011; Xu, 2014) اكثر باكترىهاى افزايش دهنده رشد كياه ممكن است سيستم

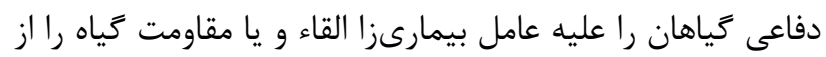

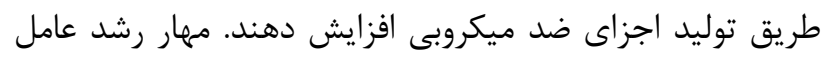

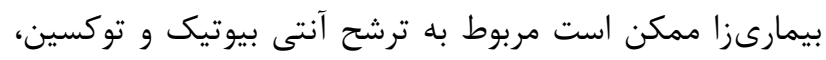

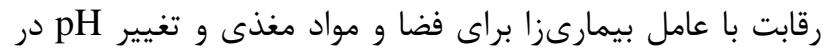

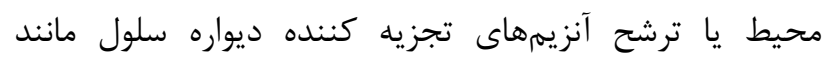

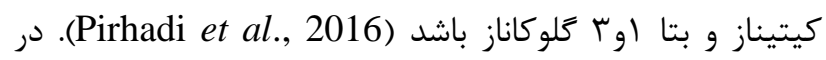

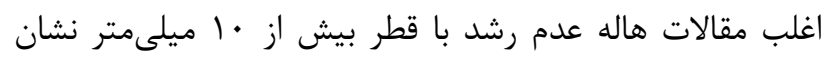

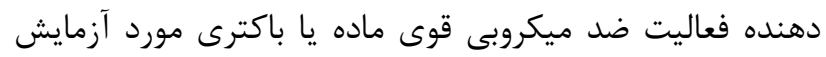

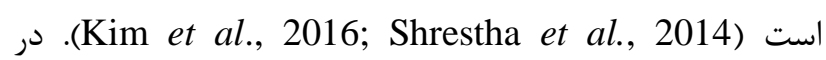
تحقيق حاضر تمام باكترىهايى كه داراى فعاليت ضد قارجى

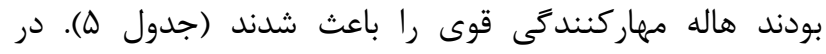
مطالعات كذشته فعاليت ضد قارجى يك سويه A. niger

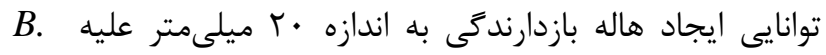
cinerea است (Chernin et al., 1995). تزارش افزايش مقاومت 


\section{REFERENCES}

Abdel-Hamid, R., Abilov, Z., Sultanova, N., Saitjanova, S. and Gemedzhieva, N. 2013. Preliminary phytochemical screening of Zygophyllum fabago. Int. J. Biol. Chem. 6: 60-4.

Afzal, I., Shinwari, Z. and Iqrar, I. 2015. Selective isolation and characterization of agriculturally beneficial endophytic bacteria from wild hemp using canola. - Pak. J. Bot. 47: 1999-2008.

Ahmad, F., Ahmad, I. and Khan, M. 2008. Screening of free-living rhizospheric bacteria for their multiple plant growth promoting activities. - Microbiol. Res. 163: 173-181.

Antoun, H. 2013. Brenner's encyclopedia of genetics. Elseivier, New York, 4368 pp.

Ashrafuzzaman, M., Hossen, F., Ismail, M., Hoque, A., Islam, M., Shahidullah, S. and Meon, S. 2009. Efficiency of plant growth-promoting rhizobacteria (PGPR) for the enhancement of rice growth. - Afr. J. Biotechnol. 8: 1247-1252.

Bartholomew, J. and Mittwer, T. 1950. A simplified bacterial spore stain. - Stain Technol. 25: 153-156.

Bhattacharyya, P. and Jha, D. 2012. Plant growthpromoting rhizobacteria (PGPR): Emergence in agriculture. - World J. Microbiol. Biotechnol. 28: 1327-1350.

Cherif-Silini, H., Silini, A., Yahiaoui, B., Ouzari, I. and Boudabous, A. 2016. Phylogenetic and plant-growthpromoting characteristics of Bacillus isolated from the wheat rhizosphere. - Ann. Microbiol. 66: 1087-1097.

Chernin, L., Ismailov, Z., Haran, S. and Chet, I. 1995. Chitinolytic enterobacter agglomerans antagonistic to fungal plant pathogens. - Appl. Environ. Microbiol. 61: 1720-1726.

Dastager, S., Deepa, C. and Pandey, A. 2010. Isolation and characterization of novel plant growth promoting Micrococcus sp. NII-0909 and its interaction with cowpea. - Plant Physiol. Biochem. 48: 987-992.

Dawwam, G., Elbeltagy, A, Emara, H., Abbas, I. and Hassan, M. 2013. Beneficial effect of plant growth promoting bacteria isolated from the roots of potato plant. - Ann. Agric. Sci. 58: 195-201.

Dobbelaere, S., Vanderleyden, J. and Okon, Y. 2003. Plant growth-promoting effects of diazotrophs in the rhizosphere. - Crit. Rev. Plant Sci. 22: 107-149.

Dworkin, M., and Foster, J. 1958. Experiments with some microorganisms which utilize ethane and hydrogen. - J. Bacteriol. 75: 592-603.

Egamberdieva, D. 2010. Growth response of wheat cultivars to bacterial inoculation in calcareous soil. Plant Soil Environ. 56: 570-573.

Faller, A., and Schleifer, K. 1981. Modified oxidase and benzidine tests for separation of staphylococci from micrococci. - J. Clin. Microbiol. 13: 1031-1035.

Felsenstein, J. 1985. Confidence limits on phylogenies: an approach using the bootstrap. - Evolution 39: 783791.

Frank, J., Reich, C., Sharma, S., Weisbaum, J., Wilson, B., and Olsen, G. 2008. Critical evaluation of two primers commonly used for amplification of bacterial 16S rRNA

$$
\begin{aligned}
& \text { عدم قابليت تحريك رشد در گياه را مىتوان به ميزان استقرار }
\end{aligned}
$$

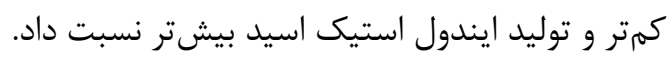

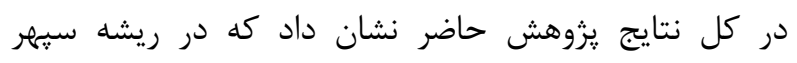

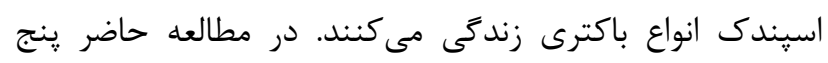

$$
\begin{aligned}
& \text { گونه باكتريايى از ريشه اسيندى جداسازى شدند. جدايههاى } \\
& \text { مورد تحقيق خصوصيات بيوشيميايى باكترىهاى تسريع كننده }
\end{aligned}
$$

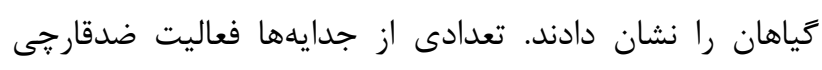

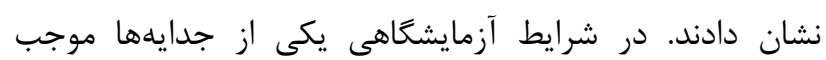

$$
\begin{aligned}
& \text { افزايش رشد اسيندك در مقايسه با تيمار شاهد و بقيه جدايهها }
\end{aligned}
$$

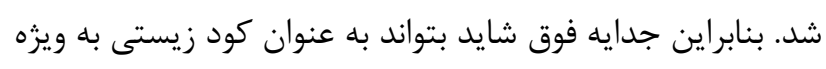

$$
\begin{aligned}
& \text { در شرايط سخت محيطى كاربرد داشته باشد. } \\
& \text { سباسخزارى } \\
& \text { نويسندكان مراتب سياس خود را از معاونت يروهش و فناورى } \\
& \text { دانشغاه شهيد مدنى آذربايجان اعلام مى كنند. }
\end{aligned}
$$


genes. - Appl. Environ. Microbiol. 74: 2461-2470.

Gordon, S., Weber, R. 1951. Colorimetric estimation of indoleacetic acid. - Plant Physiol. 26: 192-195.

Gusain, Y., Kamal, R., Mehta, C., Singh, U. and Sharma, A. 2015. Phosphate solubilizing and indole-3-acetic acid producing bacteria from the soil of Garhwal Himalaya aimed to improve the growth of rice. - J. Environ. Biol. 36: 301.

Hafeez, F., Yasmin, S., Ariani, D., Zafar, Y. and Malik, K. 2006. Plant growth-promoting bacteria as biofertilizer. - Agron. Sustain. Dev. 26: 143-150.

Hopkins, W. and Huner, N. 2012. Introduction to plant physiology. - APS press, Minnesota, 528 pp.

Khan, M., Zaidi, A., and Wani, P. 2009. Role of phosphate solubilizing microorganisms in sustainable agriculture-a review. - Agron Sustain Dev. 27: 29-43.

Khan, S., Khan, A., Khan, A., Wadood, A., Farooq, U., Ahmed, A., Ahmed V. U., Sener, B. and Erdemoglu, N. 2014. Urease inhibitory activity of ursane type sulfated saponins from the aerial parts of Zygophyllum fabago Linn. - Phytomedicine 21: 379-382.

Kim, Y., Kotnala, B., Kim, Y. and Jeon, Y. 2016. Biological characteristics of Paenibacillus polymyxa GBR-1 involved in root rot of stored Korean ginseng. - J. Ginseng. Res. 40: 453-461.

Luna, M., Galar, M., Aprea, J., Molinari, M. and Boiardi, J. 2010. Colonization of sorghum and wheat by seed inoculation with Gluconacetobacter diazotrophicus. - Biotechnol. Lett.. 32:1071-1076.

Majeed, A., Abbasi, M., Hameed, S., Imran, A. and Rahim, N. 2015. Isolation and characterization of plant growth-promoting rhizobacteria from wheat rhizosphere and their effect on plant growth promotion. - Front. Microbiol. 6: 198.

Malboobi, M., Owlia, P., Behbahani, M., Sarokhani, E., Moradi, S., Yakhchali, B., Deljou, A., Morabbi Heravi, K., 2009. Solubilization of organic and inorganic phosphates by three highly efficient soil bacterial isolates. - World J. Microbiol. Biotechnol. 25: 1471-1477.

Mishra, A., Chauhan, P., Chaudhry, V., Tripathi, M. and Nautiyal, C. 2011. Rhizosphere competent Pantoea agglomerans enhances maize (Zea mays) and chickpea (Cicer arietinum L.) growth, without altering the rhizosphere functional diversity. - Anton. Leeuw. Int. J.G. 100: 405-413.

Mufti, R., Amna Rafique, M., Haq, F., Hussain, M., Munis, M. F. H., Masood, S, Mumtaz A. S and Javed Chaudhary, H. 2015. Genetic diversity and metal resistance assessment of endophytes isolated from Oxalis corniculata. - Soil Environ. 34: 89-99.

Mumtaz, M., Ahmad, M., Jamil, M. and Hussain, T. 2017. Zinc solubilizing Bacillus spp. potential candidates for biofortification in maize. - Microbiol. Res. 202: 51-60.

Munimbazi, C., and Bullerman, L. 1998. Isolation and partial characterization of antifungal metabolites of Bacillus pumilus. - J. Appl. Microbiol. 84: 959-968.

Nicoara, A., Neagoe, A., Stancu, P., de Giudici, G., Langella, F., Sprocati, A. R., Iordache, V. and Kothe, E. 2014. Coupled pot and lysimeter experiments assessing plant performance in microbially assisted phytoremediation. - Environ. Sci. Pollut Res. 21: 6905-6920.

Pikovskaya, R., 1948. Mobilization of phosphorus in soil in connection with vital activity of some microbial species. - Mikrobiologiya 17: 362-370.

Pirhadi, M., Enayatizamir, N., Motamedi, H. and Sorkheh, K. 2016. Screening of salt tolerant sugarcane endophytic bacteria with potassium and zinc for their solubilizing and antifungal activity. Biosc. Biotech. Res. 9: 530-538.

Queipo-Ortuo, M., Colmenero, J., Macias, M., Bravo, M. and Morata, P. 2008. Preparation of bacterial DNA template by boiling and effect of immunoglobulin $G$ as an inhibitor in real-time PCR for serum samples from patients with brucellosis. - Clin. Vaccine Immunol. 15: 293-296.

Raza, F., Amin, A. and Faisal, M. 2015. Desiccationtolerant rhizobacteria from Cholistan desert, Pakistan, and their impact on Zea mays L. - Pol. J. Environ. 24: 1173-1181.

Satomi, M., La Duc, M. and Venkateswaran, K. 2006. Bacillus safensis sp. nov., isolated from spacecraft and assembly-facility surfaces. - Int. J. Syst. Evol. Microbiol. 56: 1735-1740.

Sharma, S., Sharma, M., Ramesh, A. and Joshi, O. 2012. Characterization of zinc-solubilizing Bacillus isolates and their potential to influence zinc assimilation in soybean seeds. - J. Microbiol. Biotech. 22: 352-359.

Shrestha, A., Kim, B. and Park, D. 2014. Biological control of bacterial spot disease and plant growthpromoting effects of lactic acid bacteria on pepper. Biocontrol Sci. Technol. 24: 763-779.

Simons, M., Van Der Bij, A., Brand, I., De Weger, L., Wijffelman, C. and Lugtenberg, B. 1996. Gnotobiotic system for studying rhizosphere colonization by plant growth-promoting Pseudomonas bacteria. - Mol. Plant Microbe Interact. 9: 600-607.

Son, H., Park, G., Cha, M. and Heo, M. 2006. Solubilization of insoluble inorganic phosphates by a novel salt-and pH-tolerant Pantoea agglomerans R-42 isolated from soybean rhizosphere. - Bioresour. Technol. 97: 204-210.

Tamura, K., Peterson, D., Peterson, N., Stecher, G., Nei, M. and Kumar, S. 2011. MEGA5: molecular evolutionary genetics analysis using maximum likelihood, evolutionary distance, and maximum parsimony methods - Mol. Biol. Evol. 28: 27312739.

Taylor, W., Achanzar, D. 1972. Catalase test as an aid to the identification of Enterobacteriaceae. - Appl. Microbiol. 24: 58-61

Trotel-Aziz, P., Couderchet, M., Biagianti, S., and Aziz, A. 2008. Characterization of new bacterial biocontrol agents Acinetobacter, Bacillus, Pantoea and Pseudomonas spp. mediating grapevine resistance against Botrytis cinerea. - Environ. Exp. Bot. 64: 2132 .

Turan, M., Ekinci, M., Yildirim, E., GNE, A., Karaguz, K., Kotan, R., and Dursun, A. 2014. Plant growth- 
promoting rhizobacteria improved growth, nutrient, and hormone content of cabbage (Brassica oleracea) seedlings. - Turk. J. Agric. For. 38: 327-333.

Twedt, R., Spaulding, P., and Hall, H. 1969. Morphological, cultural, biochemical, and serological comparison of Japanese strains of Vibrio parahemolyticus with related cultures isolated in the United States. - J. Bacteriol. 98: 511-518.

Verma, P., Yadav, A., Kazy, S., Saxena, A. and Suman, A. 2014. Evaluating the diversity and phylogeny of plant growth promoting bacteria associated with wheat
(Triticum aestivum) growing in central zone of India.Int. J. Curr. Microbiol. App. Sci. 3: 432-447.

$\mathbf{X u}, \mathbf{J} .2014$. Isolation and assessment of nitrogen-fixing and phosphate-solubilizing bacteria for use as biofertilizers. - Auburn University, Auburn, 145 pp.

Yoon, S., Ha, S., Kwon, S., Lim, J., Kim, Y. Seo, H. and Chun, J. 2017. Introducing EzBioCloud: a taxonomically united database of $16 \mathrm{~S}$ rRNA gene sequences and whole-genome assemblies. - Int. J. Syst. Evol. Microbiol. 67: 1613-1617.

How to cite this article:

Zadeh hosseingholi, E., Chaparzadeh, N. and Mahmudi Aghdam, S. 2020. Isolation and characterization of plant growth-promoting bacteria from Syrian bean caper (Zygophyllum fabago) rhizosphere. - Nova Biologica Rep. 6: $435-445$. (In Persian)

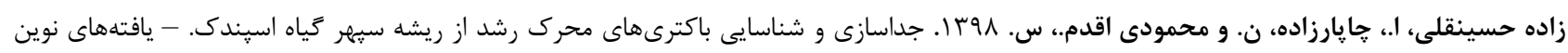

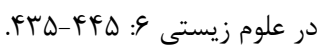

